Article

\title{
Carbonate and Oxalate Crystallization by Interaction of Calcite Marble with Bacillus subtilis and Bacillus subtilis-Aspergillus niger Association
}

\author{
Katerina V. Sazanova (nee Barinova) ${ }^{1,2,3, *}$, Olga V. Frank-Kamenetskaya ${ }^{1}(\mathbb{D}$, \\ Dmitry Yu. Vlasov ${ }^{1,2}$, Marina S. Zelenskaya ${ }^{1}{ }^{\mathbb{D}}$, Alexey D. Vlasov ${ }^{3}$, Aleksei V. Rusakov ${ }^{1} \mathbb{D}$ \\ and Maya A. Petrova 4 \\ 1 St. Petersburg State University, University emb. 7/9, 199034 St. Petersburg, Russia; \\ o.frank-kamenetskaia@spbu.ru (O.V.F.-K.); dmitry.vlasov@mail.ru (D.Y.V.); marsz@yandex.ru (M.S.Z.); \\ alex.v.rusakov@gmail.com (A.V.R.) \\ 2 Komarov Botanical Research Institute of Russian Academy of Science, Prof. Popov Street 2, \\ 197376 St. Petersburg, Russia \\ 3 The Archive of the Russian Academy of Sciences, University emb. 1, 199034 St. Petersburg, Russia; \\ alex_vlasov@mail.ru \\ 4 Institute of Molecular Genetics of Russian Academy of Science, sq. Kurchatova 2, 123182 Moscow, Russia; \\ petrova@img.ras.ru \\ * Correspondence: Ksazanova@binran.ru; Tel.: +79-65-078-93-12
}

Received: 3 August 2020; Accepted: 25 August 2020; Published: 27 August 2020

\begin{abstract}
Rock surfaces in natural systems are inhabited by multispecies communities of microorganisms. The biochemical activity of microorganisms and the patterns of microbial crystallization in these communities are mostly unexplored. Patterns of calcium carbonate and calcium oxalate crystallization induced by bacteria Bacillus subtilis and by B. subtilis together with Aspergillus niger on marble surface in vitro in liquid medium and in humidity chamber-were studied. Phase identification was supported by XRD, SEM, EDXS; metabolite composition was determined by GC-MS. It was found that the activity of $B$. subtilis-A. niger associations significantly differ from the activity of $B$. subtilis monocultures in the same trophic conditions. The phase composition and the morphology of the forming crystals are determined by the composition of the metabolites excreted by the microorganisms-particularly by the ratio of the concentrations of extracellular polymeric substances (EPS) and oxalic acid in the medium. The acidification activity of micromycetes may suppress the formation of bacterial EPS and prevent the formation of calcite. The present results can be used in the development of biotechnologies using microbial communities.
\end{abstract}

Keywords: microbial crystallization; bacterial-fungal associations; microbial metabolism; biotechnology; Bacillus spp.; Aspergillus niger; extracellular polymeric substances; calcite redeposition; oxalate crystallization; weddellite; whewellite

\section{Introduction}

Metabolism of the microbial lithobiotic community is a powerful factor in modern mineral formation [1,2]. In particular, it has been shown for number of fungal species isolated from different rock substrates [3-5] as well as for some species of bacteria [6,7]. Carbonates (mainly calcite) may form under the influence of bacteria [8-10] and oxalates (salts of oxalic acid) - under the action of microscopic fungi and lichens [4]. There are oxalate-producing bacteria (Bacillus spp., Alcaligenes sp., Actinomyces sp., Flavobacterium sp., Micrococcus sp. and others) with the participation of which both carbonates and oxalates can be formed [11]. 
The nucleation and growth of crystals of calcium carbonates under the influence of bacteria can occur in alkaline conditions on cell walls and on the surface of extracellular polymeric substances (EPS) produced by bacteria. High local concentrations of calcium ions on these surfaces are created by the electrical interaction of the negatively charged functional groups on them with the calcium ions present in the medium [12]. The shift in $\mathrm{pH}$ of the medium to the acidic values may prevent the deprotonation of EPS and consequently prevent the binding of calcium ions by functional groups of EPS. In addition, Bacillus spp. may form endospores that can lead to uncontrolled carbonate crystal growth $[12,13]$.

As for oxalate crystallization, it is well known that it occurs as a result of the interaction of rocks and minerals with oxalic acid secreted by microorganisms in a wide range of $\mathrm{pH}$ values $[4,7,14]$.

The processes of microbial metabolism are very labile and depend on the conditions of growth and existence of microorganisms $[4,15]$. The main factor affecting the metabolism of heterotrophic microorganisms is the trophic factor. As a rule, the surface of a stone contains few nutrients and such conditions are considered oligotrophic, though in some cases local conditions rich in organic matter are also possible. The study of the processes of microbial crystallization in nature requires taking these factors into account.

Rock surfaces in natural systems are inhabited by multispecies communities of microorganisms [16-19]. The biochemical activity of microorganisms in these communities and the patterns of microbial crystallization under influence of several species of microorganisms are practically unexplored.

The results of studies of bacterial carbonate crystallization and the ability of bacteria or microbial communities for calcite cementation formed the basis for practical developments for the restoration of marble and limestone monuments ("healing" of stone) [20-22]. The coprecipitation of divalent metals with calcium carbonate was suggested to remove heavy metals and radionuclides [23-25]. To date, research in the applied field is carried out in two main directions: the search for new species of bacteria capable of redepositing calcite and the selection of conditions for this process [12].

The present work continues our research on crystallization on rock surface under the influence of lithobiotic microbial communities. Before, our interests were focused mainly on the crystallization of calcium oxalates occurring during the interaction of microscopic fungi with different calcium-bearing rocks and minerals $[5,15,26]$.

The aim of this work was to reveal the differences in the metabolism of Bacillus subtilis monoculture and Bacillus subtilis-Aspergillus niger association, which are in the same trophic conditions and, on this basis, explain the morphogenetic patterns of crystallization by interaction of calcite marble with bacteria and a bacterial-fungal association.

Our study focused on the species B. subtilis because it belongs to a small group of bacteria under the influence of which both carbonates and oxalates can be formed [11,12]. This makes it possible to analyze the conditions of both processes and the interactions involved. The role of heterotrophic bacteria-including bacteria of the genus Bacillus in the formation of secondary calcite-is well studied [20,21,24,27-29], including the data from model experiments [30-33]. But the patterns of fluctuation of the metabolic activity of Bacillus spp. depending on habitat conditions has not yet been researched enough [12,20]. It is important to note that bacteria Bacillus spp. belong to Bacteria, which are widely used in biotechnology (especially in metal remediation, microbial enhanced oil recovery) and construction restoration $[20,24]$.

The choice of Aspergillus niger was due to the fact that the metabolism of this fungus and oxalate crystallization followed by interaction of calcite marble with the fungus had been studied in detail in our previous research $[5,15,26]$. In particular, we showed that $A$. niger acidification activity is very strong and increases with the increase of sugar concentration in the medium [15]. 


\section{Materials and Methods}

Two series of experiments were performed on the surface of blocks $(1 \times 1 \times 0.5 \mathrm{~cm})$ of homogeneous Carrara calcite marble with microorganisms: 1-monoculture of bacteria Bacillus subtilis, 2-co-culture of Bacillus subtilis and fungus Aspergillus niger.

\subsection{Bacterial and Fungal Strains Identification}

The bacterial strain was isolated from weathered rapakivi granite from Virolahti, Finland. It was identified by analyzing the nucleotide sequence of the most part of the 16S rRNA gene. The 16S rRNA gene was amplified from genomic DNA with the primers $63 \mathrm{~F}$ and 1387R. Genomic DNAs were extracted using a GeneJET genomic DNA purification kit (Thermo Scientific, Waltham, MA, USA). The resulting PCR products were visualized by gel electrophoresis and purified by GeneJET PCR purification kit (Thermo Scientific, Waltham, MA, USA). Sequencing of the PCR products was performed at the Inter-institute 'GENOME' Center (Moscow, Russia) using primers 537R and 1100R. Nucleotide sequences were analyzed at the website of the National Center for Biotechnology Information via the BLAST network service. According to the data obtained, the strain was identified as Bacillus subtilis. This strain was deposited in the RCAM collection under the number RCAMO4920.

The fungus Aspergillus niger (strain Ch4/07) was isolated from a damaged surface of Proconesos marble (Chersonesos, Crimea). The species identification of the strain was based on the sequence of the ITS region of rDNA (GenBank accession no-KF768341).

\subsection{Experimental Conditions}

In both series of experiments, cultivation of microorganisms was carried out in a liquid medium and in a humidity chamber (Figure 1 ) at a temperature of $+26^{\circ} \mathrm{C}$. Czapek-Dox medium (g/L: $\mathrm{NaNO}_{3}-2.0$; $\mathrm{KH}_{2} \mathrm{PO}_{4}-1.0 ; \mathrm{MgSO}_{4} \bullet 7 \mathrm{H}_{2} \mathrm{O}-0.5 ; \mathrm{KCl}-0.5 ; \mathrm{FeSO}_{4} \bullet 7 \mathrm{H}_{2} \mathrm{O}-0.01$ ) with different glucose concentration was used as a nutrient medium (the initial $\mathrm{pH}$ of medium is 5.5).

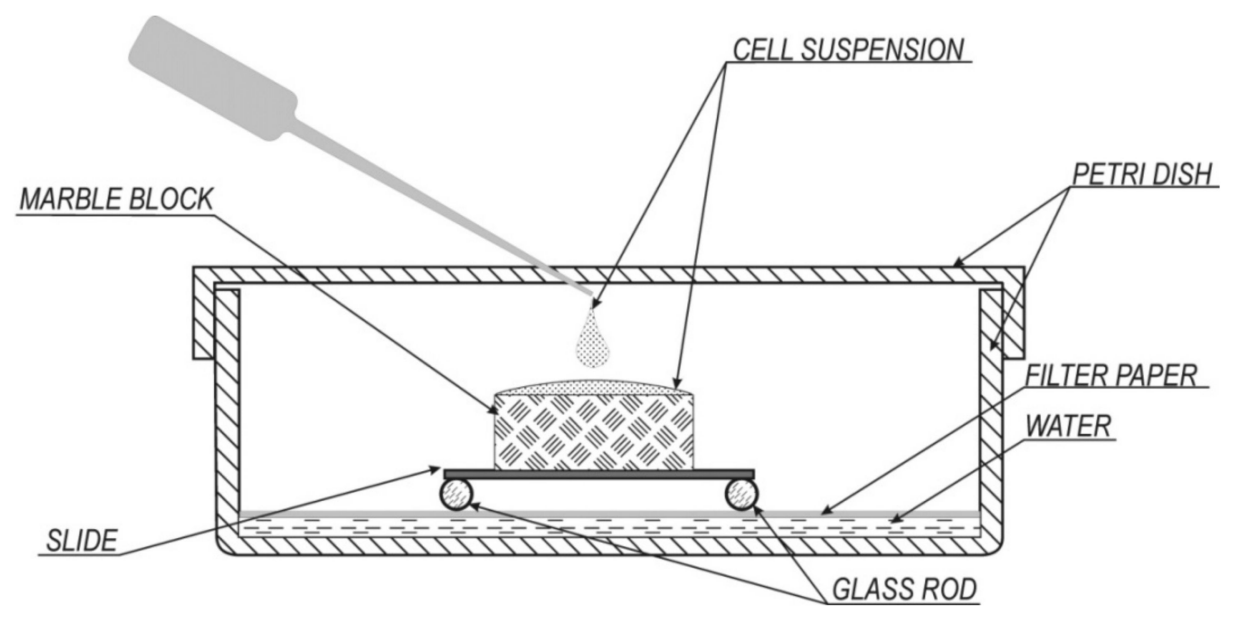

Figure 1. Scheme of the experiment in humidity chamber.

Unlike our predecessors, who used soluble salts of acetate, citrate [34], chloride [32,33], lactate and gluconate [35] as a sources of calcium for bacterially induced crystallization of calcium carbonate, we used natural calcite marble.

In the experiments in liquid medium, marble blocks were put on the bottom of Petri dishes and $15 \mathrm{~mL}$ liquid Czapek-Dox medium was added so as the surface of blocks was covered. The glucose concentration in the medium was $1,5,10$ and $30 \mathrm{~g} / \mathrm{L}$. The inoculation was carried out by the suspension of bacterial cells and fungal conidia. The number of bacterial cells in $1 \mathrm{~mL}$ of the initial suspension was 108, fungal conidia-104, which corresponds to the concentrations of cells and conidia in the destroyed limestone [36,37]. The cultivation time: 14, 21, 30 and 60 days (the last option only for 
monoculture of B. subtilis on Czapek-Dox medium with glucose $30 \mathrm{~g} / \mathrm{L}$ ). The experiments were carried out in triplicate. The Czapek-Dox medium with a fragment of marble without organisms was used as control. The culture media and the marble fragments were presterilized by autoclaving.

For the experiments in the humidity chamber (Figure 1), the same microorganism cell suspension on the basis of the liquid Czapek-Dox medium, containing 30-g/L glucose was used. The microorganism cell suspension $(0.1 \mathrm{~mL})$ was applied on the marble block surface. Humidity was maintained by periodically (once every two weeks) adding a few drops of sterile distilled water to the bottom of the Petri dish. No further nutrient medium was added. This way, the experimental conditions simulated the growth of bacteria and fungus on carbonate substrate at high humidity and with minimum amount of nutrients. The growth of microorganisms in a humid chamber is slower than in a liquid medium, therefore observation was carried out on Days 30,60 and 90. The experiments were carried out in duplicate.

The precipitate formed during the experiment, which contained crystallization products and microbial biofilmsa was investigated directly on the marble substrate.

\subsection{X-Ray Powder Diffraction (XRD)}

The XRD method was used for determination of phase composition of precipitates when the amount of crystalline material on the surface of marble or in biomass on it was at least $100 \mu \mathrm{g}$. The measurements were performed by means of Bruker"D2 Phaser" ) powder diffractometer (CuK $\alpha$ radiation of wavelength $\lambda=1.54178 \AA$, $X$-ray tube parameters were $30 \mathrm{kV} / 10 \mathrm{~mA}$; energy-dispersive one-dimensional detector DTEX/ULTRA was used) and Rigaku "MiniFlex II" powder diffractometer) (CuK $\alpha$ radiation of wavelength $\lambda=1.54178 \AA$, X-ray tube parameters were $30 \mathrm{kV} / 15 \mathrm{~mA}$; highspeed solid state energy-dispersive detector LYNXEYE was used). X-ray diffraction patterns were collected at room temperature in the range of $2 \theta=5-50^{\circ}$ with a step of $0.02^{\circ} 2 \theta$ and a counting time of half second per data point, the specimens were rotated 30 times per second during the data collection. The JCPDS PDF-2 database was used for phase identifications.

\subsection{Scanning Electron Microscopy (SEM) and Energy-Dispersive X-Ray Spectroscopy (EDXS)}

Secondary calcite and calcium oxalates (monoclinic whewellite and tetragonal weddellite) have the same EDX spectra, but substantially differ in crystal morphology $[8,9,12,29]$. This is why SEM-images of precipitates were used not only for studying the morphology of the crystals formed, but also (on par with EDXS data) for the identification of crusts of secondary calcite globules, whewellite and weddellite and detection of additional phases, which could precipitate from the Czapek-Dox medium.

The study was carried out by means of Tescan MIRA3 LMU and Jeol JCM-5000 Neoscope microscopes. Magnification range varied from $100 \times$ to $1000 \times$. Two SE detectors (secondary electron Everhart-Thornley) as well as a BSE detector (scintillation detector based on the highly sensitive YAG crystal with the resolution of $0.1 \mathrm{Z}$ of the atomic number) were used. The specimens were coated with gold $(\sim 15 \mathrm{~nm})$. Semiquantitative EDX elemental analysis was performed by means of Tescan MIRA3 LMU Advanced Aztec Energy (IE350)/X-max80 system with guaranteed spectral resolution on the line $\mathrm{Mn} \mathrm{K} \alpha-127 \mathrm{eV}$.

\subsection{Determination of Biomass Content}

The biomass of microorganisms was determined by the gravimetric method. The surface mycelium and cell pellet obtained after centrifugation of cultural liquid with microbial biomass (at 11,000 rpm for $10 \mathrm{~min}$ ) were used to determine the biomass of microorganisms. The microbial biomass was dried at $60{ }^{\circ} \mathrm{C}$ to an absolutely dry weight.

\subsection{Chromatography-Mass Spectrometry (GC-MS Analysis)}

The determination of the metabolite composition was carried out in a liquid medium with the marble in monoculture of bacterium B. subtilis and in the co-culture of B. subtilis and A. niger using gas 
chromatography-mass spectrometry (GC-MS). To determine the total content of organic acids in the cultural fluid, test samples were treated with $0.1-\mathrm{M} \mathrm{HCl}$ up to $\mathrm{pH} 1.0$ in order to dissolve insoluble salts. Further an aliquot of the filtrate was passed through cationic exchanger (KU-2-8) to free acids from their salts. The obtained water solution of organic acids was evaporated, and the dry residue was dissolved in pyridine.

Carbon acids extracted from the cultural fluid were analyzed as trimethylsilyl derivatives by use of an Agilent mass spectrometer (MSD5975 mass selective detector), column HP-5MS, $30 \mathrm{~m} 90.25 \mathrm{~mm}$. Chromatography was carried out with linear temperature programming from 70 to $320{ }^{\circ} \mathrm{C}$ at the speed of $4{ }^{\circ} \mathrm{C} / \mathrm{min}$. Data were collected using Agilent Chem Station software. Mass spectrometric information was processed and interpreted using AMDIS program (http://www.amdis.net/index.html) and standard NIST2005 library. Quantitative interpretation of chromatograms was carried out with the internal C23 standardization using UniChrom program (http://www.unichrom.com/unichrome.shtml).

\subsection{Determination of EPS Content}

The analysis of the EPS content in the liquid monoculture of B. subtilis and in co-culture of B. subtilis and $A$. niger was performed on the 21 day of the cultivation by the method described previously in Savadogo et al. 2004 [38].This method allowed us to quantify the EPS and was chosen due to its simplicity and adequacy for the task. Previously marble blocks (after exposed to microbes) were removed from the solution. The culture was centrifuged at $11,000 \mathrm{rpm}$ for $10 \mathrm{~min}$. The collected supernatant was mixed with an equal volume of ice-cold ethanol and incubated at $4{ }^{\circ} \mathrm{C}$ for $24 \mathrm{~h}$. The refrigerated solution was then centrifuged at $2500 \mathrm{rpm}$ for $20 \mathrm{~min}$. The obtained pellets were resuspended in distilled water, along with an equal volume of ice-cold ethanol. The solution was then centrifuged again at $2500 \mathrm{rpm}$ for $20 \mathrm{~min}$. The final pellet obtained was dried at $60{ }^{\circ} \mathrm{C}$ and weighed.

\subsection{Determination of $\mathrm{pH}$ Values}

The $\mathrm{pH}$ values during the experiment were evaluated using a $\mathrm{pH}$ meter Checker 1 (HI 98,103).

\section{Results}

\subsection{The Growth of Biomass on the Mineral Surface}

As shown in the example on the 21st day of the experiment, the amount of B. subtilis biomass was significantly lower than the B. subtilis + A. niger (Table 1 ). With the increase of glucose concentration an increase in culture biomass was observed. At a low glucose concentration $(1 \mathrm{~g} / \mathrm{L})$, the fungus grew slowly, and the total biomass content was only two times higher than its content in the bacterial monoculture at the same glucose concentration. At a higher glucose concentration $(10$ and $30 \mathrm{~g} / \mathrm{L})$, the biomass of the B. subtilis-A. niger association was significantly ( 8 and 6 times, respectively) higher than the biomass of bacterial monoculture at the same glucose concentrations, as well as the biomass of the $B$. subtilis $-A$. niger association at a glucose concentration of $1 \mathrm{~g} / \mathrm{L}(\sim 6$ times).

3.2. The Metabolism of Bacillus subtilis and Bacillus subtilis with Aspergillus niger in the Cultural Liquids at Different Glucose Levels

\subsubsection{Acid Production}

The analysis of B. subtilis liquid culture revealed that extracellular low-weight carbonic acids produced by bacteria include 2-hydroxypropanoic acid, oxalic and succinic acids. Oxalic acid directly involved in the formation of calcium oxalate was found in the medium at different glucose concentrations on the 21st day of the experiment (Table 1). On the 30th day the amount of oxalic acid slightly increased. 
Table 1. Metabolic products of microorganisms and $\mathrm{pH}$ values in cultural liquids at various glucose concentrations.

\begin{tabular}{|c|c|c|c|c|c|c|c|c|c|}
\hline \multirow{3}{*}{ Organism } & \multirow{3}{*}{$\begin{array}{c}\text { Glucose } \\
\text { Content, g/L }\end{array}$} & \multicolumn{8}{|c|}{ Days of Growth } \\
\hline & & \multicolumn{2}{|c|}{14} & \multicolumn{4}{|c|}{21} & \multicolumn{2}{|c|}{30} \\
\hline & & $\mathrm{pH}$ & $\begin{array}{c}\text { Oxalic Acid, } \\
\mu \mathrm{g} / \mathrm{mL}\end{array}$ & $\mathrm{pH}$ & $\begin{array}{c}\text { Biomass, } \\
\mathrm{mg} / 100 \mathrm{~mL}\end{array}$ & $\begin{array}{c}\text { Oxalic Acid, } \\
\mu \mathrm{g} / \mathrm{mL}\end{array}$ & EPS, $\mu \mathrm{g} / \mathrm{mL}$ & $\mathrm{pH}$ & $\begin{array}{c}\text { Oxalic Acid, } \\
\mu \mathrm{g} / \mathrm{mL}\end{array}$ \\
\hline \multirow{4}{*}{ Bacillus subtilis } & 1 & 7.5 & not found & 7.8 & $0.33 \pm 0.01$ & $1.0 \pm 0.4$ & $328 \pm 44$ & 8.2 & $1.1 \pm 0.3$ \\
\hline & 5 & 7.5 & not found & 8.2 & $0.38 \pm 0.02$ & $0.6 \pm 0.4$ & $405 \pm 58$ & 8.6 & $1.0 \pm 0.3$ \\
\hline & 10 & 7.0 & not found & 7.4 & $0.46 \pm 0.05$ & $1.1 \pm 0.3$ & $1121 \pm 181$ & 8.0 & $1.5 \pm 0.3$ \\
\hline & 30 & 6.5 & not found & 7.2 & $0.678 \pm 0.01$ & $0.8 \pm 0.1$ & $1460 \pm 204$ & 8.1 & $3.4 \pm 0.4$ \\
\hline \multirow{3}{*}{$\begin{array}{c}\text { Bacillus subtilis } \\
+ \text { Aspergillus } \\
\text { niger }\end{array}$} & 1 & 7.5 & $2.2 \pm 0.5$ & 8.0 & $0.64 \pm 0.02$ & $2.0 \pm 0.1$ & $437 \pm 66$ & 8.0 & $15.5 \pm 2.0$ \\
\hline & 10 & 4.5 & $153.8 \pm 13.4$ & 5.0 & $3.80 \pm 0.04$ & $1032.9 \pm 89.1$ & $1.1 \pm 0.2$ & 7.0 & $1740.0 \pm 99.4$ \\
\hline & 30 & 3.0 & $740.0 \pm 20.8$ & 5.5 & $4.11 \pm 0.08$ & $3275.3 \pm 232.1$ & $10 \pm 2$ & 5.0 & $5275.1 \pm 100.4$ \\
\hline
\end{tabular}


In the co-culture of B. subtilis with A. niger only oxalic acid was released in medium with low glucose concentration $(1 \mathrm{~g} / \mathrm{L})$. At a glucose concentration of 5-30 g/L, oxalic, succinic, fumaric, malic, citric and gluconic acids were produced by the culture. The amount of succinic, fumaric, malic, citric and gluconic acids were the highest on Day 21 of growth and increased with the increase of glucose concentration: from 0.2 to $55 \mu \mathrm{g} / \mathrm{mL}$ for succinic acid, from 0.2 to $43 \mu \mathrm{g} / \mathrm{mL}$ for fumaric acid, from 0.4 to $320 \mu \mathrm{g} / \mathrm{mL}$ for malic acid, from 0.3 to $4570 \mu \mathrm{g} / \mathrm{mL}$ for citric acid and from 200 to $380 \mu \mathrm{g} / \mathrm{mL}$ for gluconic acid. The amount of oxalic acid in co-culture of B. subtilis with A. niger on Days 14 and 21 of the experiment with glucose concentration $1 \mathrm{~g} / \mathrm{L}$ reached $2 \mu \mathrm{g} / \mathrm{mL}$, which was only twice as much as with the same glucose content in the culture of B. subtilis on Day 21 of the experiment (Table 1). After 30 days of cultivation the content of oxalic acid increased to $15 \mu \mathrm{g} / \mathrm{mL}$. When the glucose concentration was 10 and $30 \mathrm{~g} / \mathrm{L}$, the amount of oxalic acid increased sharply (on Day 14 by 2 orders of magnitude and on Days 21 and 30 by three orders of magnitude. Thus, in liquid co-culture of B. subtilis with A. niger, between the sugar concentration and the content of oxalic acid there was a pronounced direct relationship (Table 1).

\subsubsection{The Extracellular Polymer Matrix Formation}

On the 21st day of the experiment, at low glucose concentrations ( 1 and $5 \mathrm{~g} / \mathrm{L}$ ), the total content of EPS in the monoculture of B. subtilis and in co-culture of B. subtilis and A. niger was similar (Table 1). With an increase of the sugar concentration in the medium with the monoculture of bacteria the amount of EPS increased, but in co-culture of B. subtilis and A. niger content of EPS decreased. Thus, in monoculture of $B$. subtilis there was a distinct linear relationship between sugar and EPS concentrations and in the co-culture system of B. subtilis and A. niger-the inverse of this.

\subsubsection{Changes of $\mathrm{pH}$ Value}

In the Czapek-Dox medium with a fragment of marble without organisms (control experiment) the $\mathrm{pH}$ value increased from the initial $\mathrm{pH}$ value 5.5 up to 6.5 over 30 days. In the experiments with B. subtilis, the $\mathrm{pH}$ value increased with time more quickly (Table 1). In the co-culture of the fungus and bacteria, at glucose concentrations of $1 \mathrm{~g} / \mathrm{L}$ in intervals from 14 to 30 days pHvalues close to fixed in monoculture of bacteria at low glucose concentrations (increased from 7.5 to 8.0) (Table 1). With increasing glucose concentration $(10$ and $30 \mathrm{~g} / \mathrm{L})$ on Day 14 of the experiment, the pHvalue of cultural liquid decreased. With time, the pHvalues in the co-culture of the fungus and bacteria began to grow slowly.

\subsection{The Phase Composition of Synthesis Products and the Morphology of Crystals}

\subsubsection{The Experiments with B. subtilis}

\section{Liquid Medium}

In the experiment with $B$. subtilis, the secondary calcite globules were observed on SEM images after 14, 21 and 30 days of the experiment with glucose concentrations of 30,10,1 g/L accordingly at $\mathrm{pH}$ of $6.5,7.4$ and 8.2, respectively (Table 2; Figures 2a-d and 3). At glucose concentration of $30 \mathrm{~g} / \mathrm{L}$, after 21 days the thickness of calcite crust reached $5 \mu \mathrm{m}$ (calcite globule sizes were $\sim 2-3 \mu \mathrm{m}$ ) (Figure $2 \mathrm{~b}$ ). After 60 days of the experiment, the thickness at $\mathrm{pH} 11$ of a continuous calcite crust on the marble surface was $\sim 20 \mu \mathrm{m}$ (Figure 2c). 
Table 2. Phase composition of the precipitations and the morphology of the crystals formed under action of microorganisms during the experiment.

\begin{tabular}{|c|c|c|c|c|c|c|}
\hline \multirow{5}{*}{$\begin{array}{c}\text { Days of } \\
\text { Experiment }\end{array}$} & \multicolumn{6}{|c|}{ Organisms } \\
\hline & \multicolumn{3}{|c|}{ B. subtilis } & \multicolumn{3}{|c|}{ B. subtilis + A. niger } \\
\hline & \multicolumn{6}{|c|}{ Liquid Medium } \\
\hline & \multicolumn{6}{|c|}{ Glucose Concentration, $\mathrm{g} / \mathrm{L}$} \\
\hline & 1 & 10 & 30 & 1 & 10 & 30 \\
\hline 14 & \multicolumn{2}{|c|}{ Marble dissolution } & $\begin{array}{l}\text { Separate clusters of small } \\
\text { calcite globules, small } \\
\text { content of whewellite, } \\
\text { numerous intergrowths } \\
\text { of brushite crystals }\end{array}$ & \multicolumn{2}{|l|}{ Strong marble dissolution } & $\begin{array}{l}\text { Single dipyramidal- } \\
\text { prismatic weddellite crystals } \\
\text { in a continuous carpet of } \\
\text { plate whewellite crystals }\end{array}$ \\
\hline 21 & Marble dissolution & $\begin{array}{l}\text { Separate clusters of small } \\
\text { calcite globules }\end{array}$ & $\begin{array}{l}\text { The beginning of calcite } \\
\text { crust formation } \\
\text { (thickness } 5-10 \mu \mathrm{m}), \\
\text { small content of } \\
\text { whewellite, numerous } \\
\text { intergrowths of brushite } \\
\text { crystals }\end{array}$ & $\begin{array}{l}\text { Separate clusters of small globules of secondary calcite, } \\
\text { single dipyramidal weddellite and plate-like whewellite } \\
\text { crystals. }\end{array}$ & $\begin{array}{l}\text { Massive dipyramidal } \\
\text { weddellite crystals in } \\
\text { continuous carpet of } \\
\text { plate whewellite crystals }\end{array}$ & $\begin{array}{l}\text { Massive dipyramidal and } \\
\text { dipyramidal- } \\
\text { prismatic weddellite crystals } \\
\text { and numerous whewellite } \\
\text { spherulitic intergrowths }\end{array}$ \\
\hline 30 & $\begin{array}{l}\text { Separate clusters of small } \\
\text { calcite globules, small } \\
\text { content of the whewellite, } \\
\text { numerous intergrowths } \\
\text { of brushite crystals }\end{array}$ & $\begin{array}{l}\text { The beginning of calcite crust } \\
\text { formation (thickness } \\
5-10 \mu \mathrm{m}), \text { small content of } \\
\text { the whewellite, numerous } \\
\text { intergrowths of brushite } \\
\text { crystals }\end{array}$ & $\begin{array}{c}\text { Continuous calcite crust } \\
\text { (thickness up to } 20 \mu \mathrm{m} \text { ), } \\
\text { small content of } \\
\text { whewellite, numerous } \\
\text { intergrowths of brushite } \\
\text { crystals }\end{array}$ & \multicolumn{3}{|c|}{$\begin{array}{l}\text { Massive dipyramidal and dipyramidal-prismatic } \\
\text { weddellite crystals and numerous whewellite spherulitic } \\
\text { intergrowths }\end{array}$} \\
\hline \multicolumn{7}{|c|}{ Humidity chamber } \\
\hline & 30 & \multirow{3}{*}{\multicolumn{2}{|c|}{ Separate dipyramidal weddellite crystals }} & \multirow{3}{*}{\multicolumn{3}{|c|}{ Separate dipyramidal-prismatic weddellite crystals }} \\
\hline & 60 & & & & & \\
\hline & 90 & & & & & \\
\hline
\end{tabular}




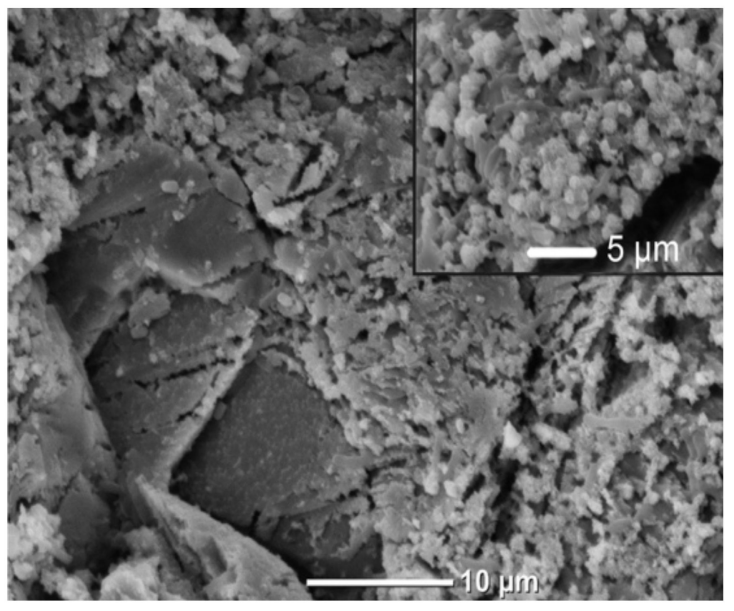

(a)

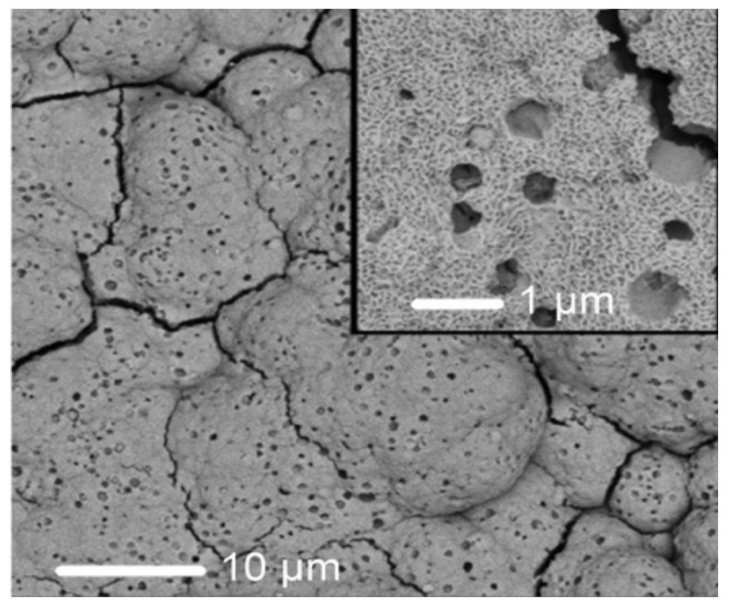

(c)

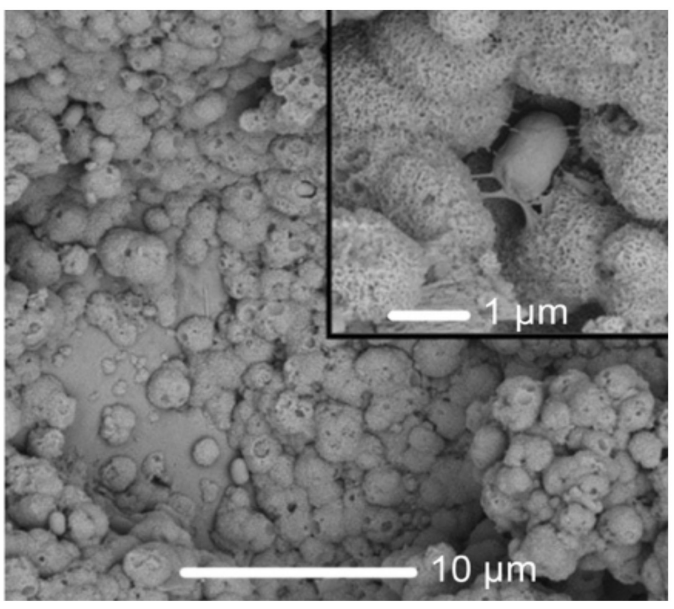

(b)

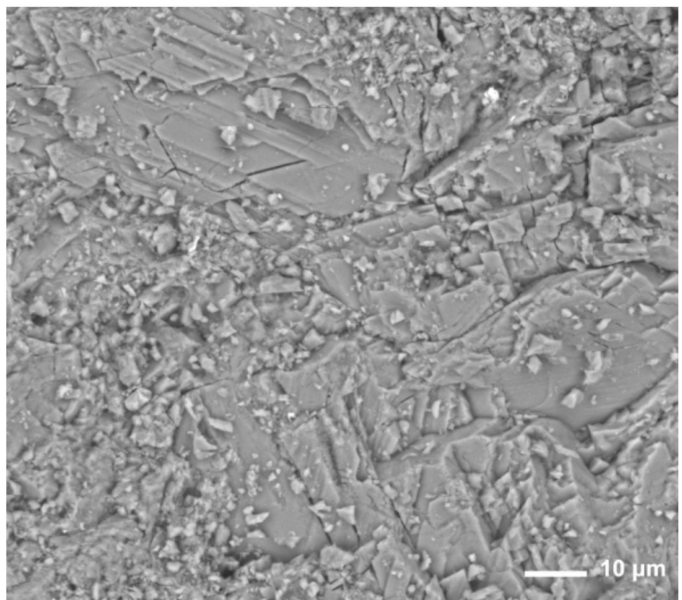

(d)

Figure 2. SEM images of marble surface in experiment with glucose concentration $30 \mathrm{~g} / \mathrm{L}$ under the action of B. subtilis. (a) 14 days; (b) 21 days; (c) 60 days; (d) control (without bacteria).

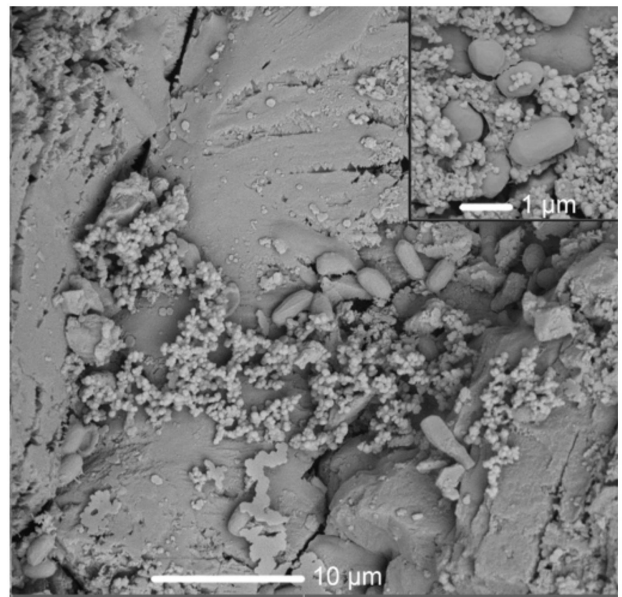

(a)

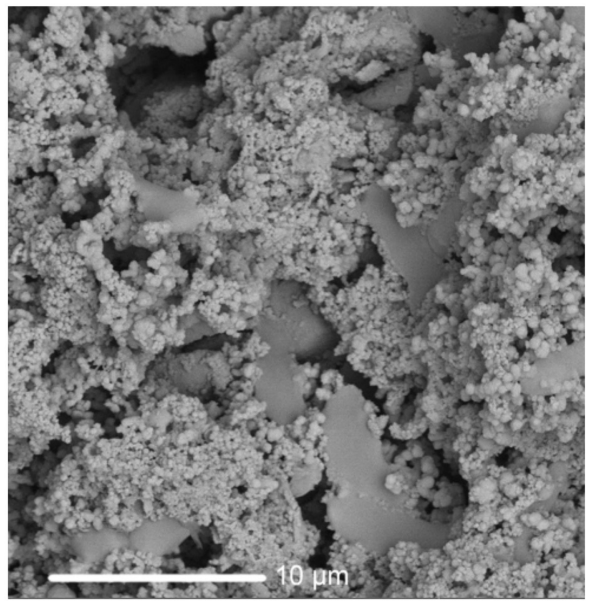

(b)

Figure 3. SEM images of secondary calcite formation on marble surface under the action of bacteria B. subtilis after 30 days inoculation with different glucose concentrations. (a) $1 \mathrm{~g} / \mathrm{L}$; (b) $10 \mathrm{~g} / \mathrm{L}$. 
Bacterial cells associated with calcite globules by mucous cords were visible on the surface of the original marble substratum and on the newly formed calcite globules (Figure 2b, inset).

It was shown that an increase in glucose concentration leads to a more intense formation of secondary calcite (Figure 3). At a low glucose concentration $(1 \mathrm{~g} / \mathrm{L})$ on the 30th day of the experiment, separate clusters of small calcite globules (sized less than $0.2 \mu \mathrm{m}$ ) were visible, cemented together with bacterial cells in an exopolysaccharide matrix (Figure 3a). With an increase of glucose concentration $(10 \mathrm{~g} / \mathrm{L})$ on the 30th day of the experiment, an increase of number and size of secondary calcite globules was observed (up to $1 \mu \mathrm{m}$ ) (Figure $3 \mathrm{~b}$ ).

In addition, after 30 days of the experiment performed in the presence of $B$. subtilis; at different concentrations of glucose in the medium (from 1 to $30 \mathrm{~g} / \mathrm{L}$ ), numerous intergrowths of elongated tabular brushite crystals $\mathrm{CaHPO}_{4} \bullet 2 \mathrm{H}_{2} \mathrm{O}$ (length from 50 to $200 \mu \mathrm{m}$ ) on the surface of the secondary calcite crust were observed (Figure 4a). Smaller calcite globules of a next generation were visible on the surface. There were no visible crystals of calcium oxalate on SEM images. However, the XRD analysis of the crystallization products formed by the B. subtilis participation at different concentrations of glucose in the medium (from 1 to $30 \mathrm{~g} / \mathrm{L}$ ), performed after 30 days of the experiment, showed the presence of a small content of the calcium oxalate monohydrate whewellite $\mathrm{CaC}_{2} \mathrm{O}_{4} \bullet \mathrm{H}_{2} \mathrm{O}$ (Figure 4a).

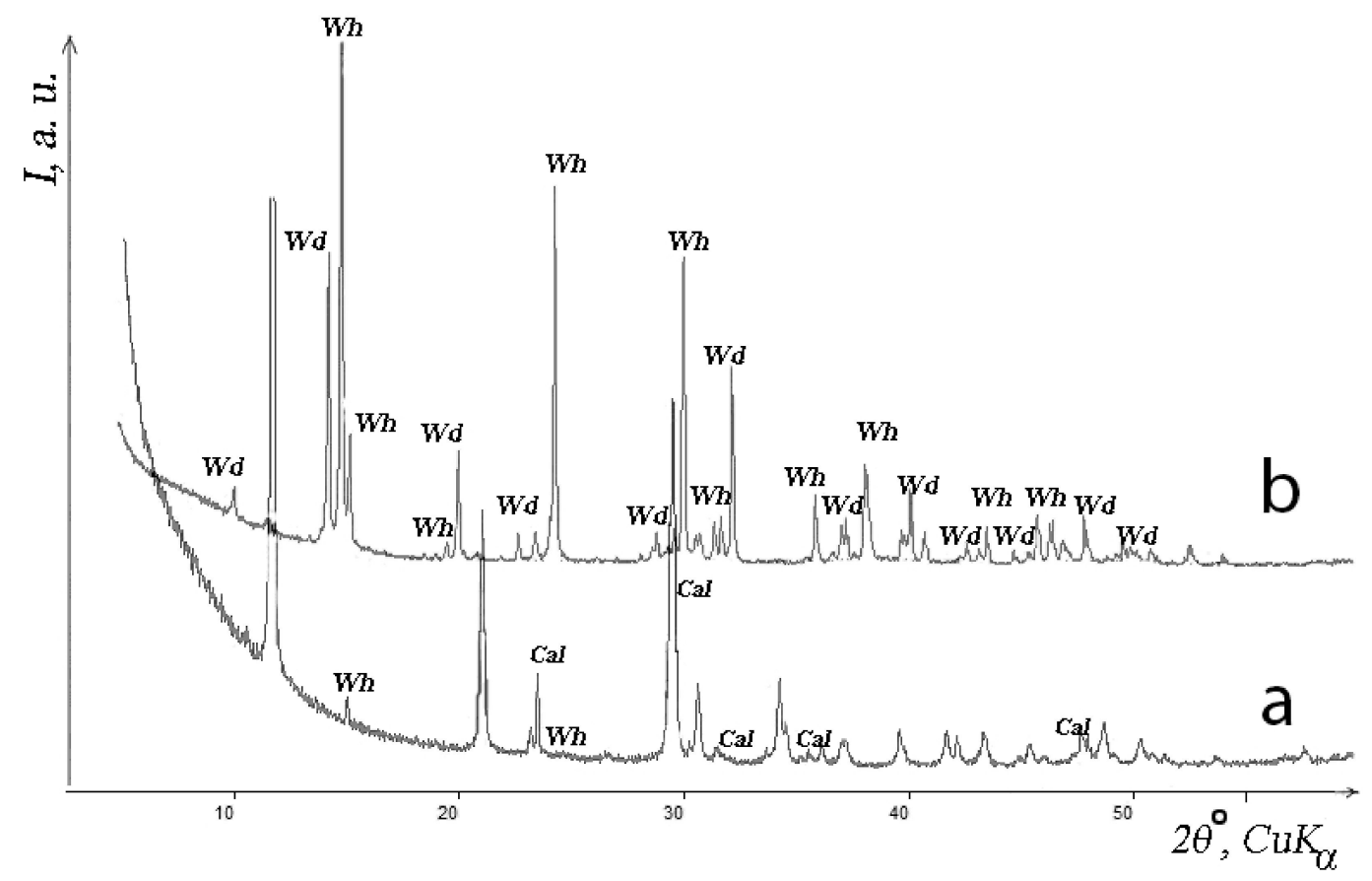

Figure 4. Powder X-ray diagram of crystallization products formed in liquid Czapek-Dox medium under the influence of microorganisms. (a) On marble block by Bacillus subtilis (30 days, 1-g/L glucose); (b) in biomass from marble block by B. subtilis with $A$. niger (21 days, 30-g/L glucose). Key: Cal—calcite; $\mathrm{Wd}$-weddellite; Wh-whewellite. Unmarked peaks belong to brushite.

A control experiment showed that in the absence of the bacteria secondary calcite crust formation did not occur.

Humidity Chamber

The results of the experiments with bacteria B. subtilis in humidity chamber differed from the results obtained in liquid medium. Single dipyramidal crystals of tetragonal calcium oxalate dihydrate weddellite $\mathrm{CaC}_{2} \mathrm{O}_{4} \bullet(2.5-\mathrm{x}) \mathrm{H}_{2} \mathrm{O}$ were found on the marble surface after 30 days of cultivation (Table 2). After 3 months of cultivation, the number of dipyramidal crystals (50-70 crystals ranging from 10 to $40 \mu \mathrm{m}$ per $1 \mathrm{~mm}^{2}$ ) did not increase (Figure $5 \mathrm{a}$ ). Bacterial cells were located both on the surface of the 
oxalate crystals and around them. Secondary calcite on marble surface even after 90 days of incubation was not obtained.

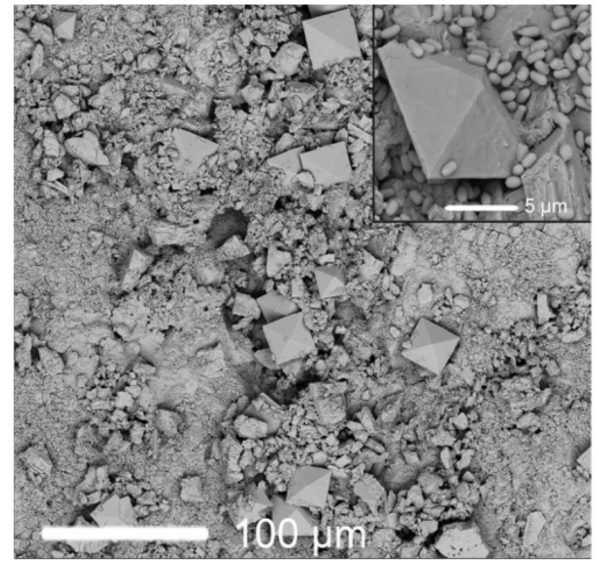

(a)

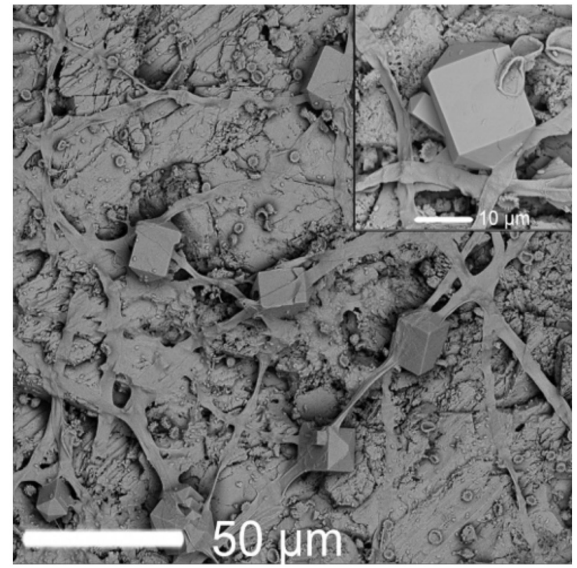

(b)

Figure 5. Weddellite crystals formed in humidity chamber on marble surface after 90 days of incubation with microorganisms. (a) B. subtilis; (b) B. subtilis with A. niger.

3.3.2. The experiments with $B$. subtilis and A. niger

\section{Liquid Medium}

In the experiments with $B$. subtilis and A. niger in the liquid medium along with bacterial cells fungal hyphae the marble blocks surfaces were observed. The phase composition of the crystallization products and the morphology of the formed crystals depend significantly on the glucose concentration in the nutrient medium (Table 2). On the 14th day of the experiment at glucose concentration $30 \mathrm{~g} / \mathrm{L}$ the marble dissolution was more intense than in a similar experiment with $B$. subtilis only. The formation of single tetragonal dipyramidal-prismatic weddellite crystals and numerous plate-like monoclinic whewellite crystals were observed, secondary calcite formation was not observed. On the 21st day of the experiment globules of secondary calcite on the marble surface were observed by $\mathrm{pH}=8$ only at a low glucose concentration ( $1 \mathrm{~g} / \mathrm{L}$ ) (Figure $6 \mathrm{a}$ ). Along with calcite globules, calcium oxalate crystals were present on the surface of marble: dipyramidal (almost isometric) weddellite crystals and plate-like whewellite crystals. The size of weddellite crystals varies from 10 to $25 \mu \mathrm{m}$. Whewellite plate-like crystals $(5-40 \mu \mathrm{m})$ form stack-like intergrowths. In the experiment with glucose concentration of $10-30 \mathrm{~g} / \mathrm{L}$ at $\sim \mathrm{pH} 5$ secondary calcite was not observed (Figures $4 \mathrm{~b}$ and $6 \mathrm{~b}, \mathrm{c}$ ). At a glucose concentration of $10 \mathrm{~g} / \mathrm{L}$, massive dipyramidal weddellite crystals (up to $100 \mu \mathrm{m}$ ) were observed being stuck in the continuous carpet of plate-like whewellite crystals (up to $30 \mu \mathrm{m}$ each, Figure $6 \mathrm{~b}$ ). At a glucose concentration of $30 \mathrm{~g} / \mathrm{L}$, numerous spherulitic whewellite intergrowths (up to $80 \mu \mathrm{m}$ ) and weddellite crystals of approximately the same size were found (Figure 6c). Some of the observed weddellite crystals had prismatic faces as well as dipyramidal ones.

\section{Humidity Chamber}

In the experiment with B. subtilis and A. niger in the humidity chamber the formation of weddellite crystals was observed from 30 to 90 days of the experiment (Figure 5b, Table 2).The size ratio between the prism faces and dipyramidal faces was different from the case with bacteria only: the prism faces were considerably bigger than the dipyramidal ones. The number of Ca oxalate crystals formed on the $1 \mathrm{~mm}^{2}$ of marble surface in experiments in the B. subtilis monoculture (Figure 5a) and in the B. subtilis and $A$. niger co-culture (Figure $5 b$ ) was about the same. 


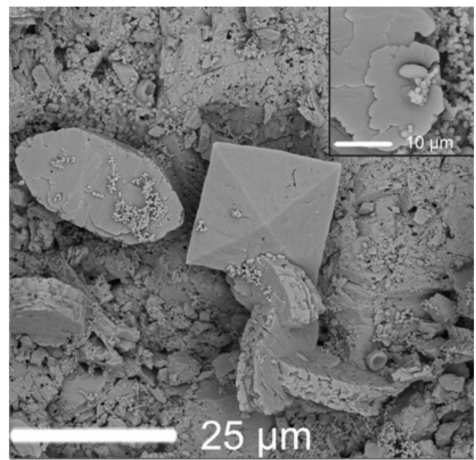

(a)

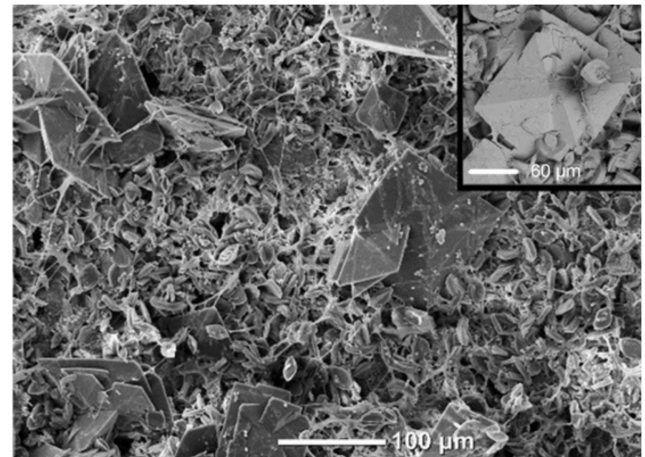

(b)

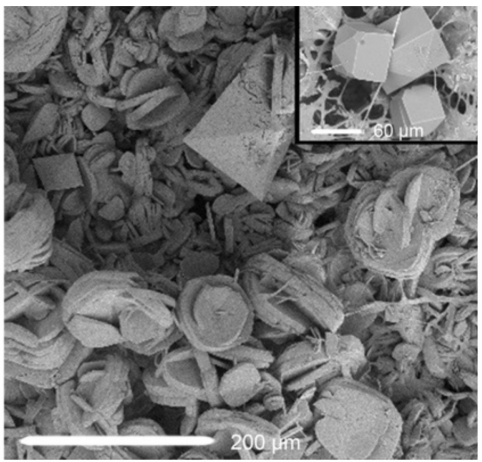

(c)

Figure 6. Crystals on marble surface formed by participation of bacteria B. subtilis and fungus A. niger in liquid medium after 21 days of cultivation, depending on the glucose concentration in the medium. (a) $1 \mathrm{~g} / \mathrm{L}$; (b) $10 \mathrm{~g} / \mathrm{L}$; (c) $30 \mathrm{~g} / \mathrm{L}$.

\section{Discussion}

The results of present research showed that glucose contents in the liquid medium significantly affect the microbial metabolism and the variations of $\mathrm{pH}$ values. In monoculture bacteria and in bacterial-fungal associations, this influence is different (Table 1). The experiments performed in liquid monoculture of $B$. subtilis showed that the addition of nutrients in the medium (raising the amount of glucose from 1 to $30 \mathrm{~g} / \mathrm{L}$ ) leads to a more intense EPS production (in our case five times more intense) and almost not affect oxalic acid production. In the liquid co-culture of $B$. subtilis and $A$. niger the same addition of glucose leads to a distinct rise of the amount of oxalic and other acids excreted by microorganisms (by 2-3 orders of magnitude). At the same time the content of EPS is decreased (it was shown on the example of 21 days). It is known that $A$. niger acidification activity increases with the increase of sugar concentration [15] and there is no doubt that the intensive formation of organic acids by fungi under conditions of additional nutrition, can suppress the formation of bacterial EPS. However, the question remains as whether acidification activity of bacteria is preserved or possibly even increases.

The $\mathrm{pH}$ values of the medium largely depend on the composition of the metabolites secreted by bacteria and fungi. In turn, the acidity of the medium significantly affects the metabolism of microorganisms. The optimal $\mathrm{pH}$ value for bacterial EPS production of genus Bacillus is between seven and eight [13]. The same $\mathrm{pH}$ were observed in our experiment in liquid monoculture of B. subtilis. The observed slight fluctuations in the $\mathrm{pH}$ of the medium with similar values of oxalic acid (Table 1) may be associated with variations in the concentrations of other acids excreted by B. subtilis. It should also be kept in mind that the crystallization of calcium oxalate leads to a decrease in the content of oxalate ions in the medium and may lead to an increase in $\mathrm{pH}$. An increase in $\mathrm{pH}$ is often observed also in aging cultures of microorganisms and may be a consequence of the release of nitrogen metabolism 
products by bacteria, as well as the formation of lysis products of aging cells $[5,39,40]$. Since the $\mathrm{pH}$ increases with time, it can be concluded that the influence of factors contributing to the increase in $\mathrm{pH}$ (in particular, the products of nitrogen metabolism) prevails in our experiment. The influence of fungal culture on the metabolism of bacteria is also connected with $\mathrm{pH}$ of the medium. According to our experimental data the release of oxalic acid by fungus reduces the $\mathrm{pH}$ of the medium which results in inhibition of the EPS formation by bacteria. The fact that the acidic environment is not favorable for the formation of bacterial EPS had already been discussed [13].

Our results have demonstrated that the phase composition of the products of microbial crystallization is controlled by $\mathrm{pH}$ value which is associated with the ratio between the EPS and oxalic acid concentration in the cultural broth. In the monoculture of B. subtilis the amount of EPS was always higher than the amount of oxalic acid (Table 1) which resulted in the crystallization of secondary calcite in a low alkaline medium. The intensity of carbonate crystallization increased with the increase of the amount of sugar and consequently the amount of EPS in the medium (Figures 2 and 3). Only after 30 days of the experiment small amounts of calcium oxalate monohydrate (whewellite) were found in the crystallization products (Figure 4a). In liquid co-culture of B. subtilis and A. niger EPS concentration is lower than in B. subtilis monoculture and oxalic acid concentration is higher. The ratio between EPS and oxalic acid content decreases with the increase of the amount of sugar in the medium, which is accompanied by a decrease in $\mathrm{pH}$. When the amount of glucose is one gram per liter, the EPS concentration is higher than the amount of oxalic acid by 200 times and at $\mathrm{pH}=8$ calcite and both calcium oxalates (weddellite and whewellite) crystallize simultaneously (Figure 6a). The crystallization of the metastable weddellite in the range of the stable whewellite may occur if the content of $\mathrm{Ca}^{2+}$ ions exceeds the content of oxalate ions in medium as well in the presence of citric acid in it, and therefore depends on the metabolic activity of the fungi [41]. With the increase of the amount of glucose $(\geq 10 \mathrm{~g} / \mathrm{L})$, oxalic acid concentration gets substantially higher than EPS concentration (not less than by 1000 times), $\mathrm{pH}$ decreases down to 5 , and the conditions become favorable only for oxalate crystallization (Figure $6 \mathrm{~b}, \mathrm{c}$ ). Thus, the obtained data demonstrate that the metabolic activity of microscopic fungi (in our case A. niger) can suppress the formation of bacterial EPS and prevent the calcite formation.

When incubation occurs in oligotrophic conditions in the humidity chamber the amounts of the excreted metabolites is small. The products of crystallization on the marble surface are represented by calcium oxalate dihydrate (weddellite) (Figure 5). The presence of weddellite and the absence of secondary calcite allow to suggest that the conditions of the humidity chamber are not favorable for EPS accumulation. In the experiment with B. subtilis monoculture a high concentration of oxalate ions was induced only by the bacterial metabolism. This was favored by the initial concentration of bacterial cells which was 16 times higher than in the experiment in the liquid medium. In the experiment with B. subtilis and A. niger co-culture the intensity of weddellite crystallization was practically the same as in the experiment with $B$. subtilis monoculture. It means that the oxalate crystallization was inhibited because the amount of nutrient substances was lacking. It can be assumed that at the beginning of the experiment, oxalate crystallization in the humidity chamber took place in an acidic environment unfavorable for the formation of EPS. However, as the calcium oxalates crystallized and the cultures of microorganisms aged, an increase in the initial $\mathrm{pH}$ value may have occurred [5,26]. This suggests that if the nutrient substances in the humidity chamber are still preserved the carbonate crystallization can take place after the oxalate crystallization. This assumption is confirmed by the metamorphose of secondary calcite over the split whewellite crystals observed by us in an earlier experiment, which we carried out in a humidity chamber with bacteria B. subtilis and fungus Penicillium sp. [26].

The morphology of the formed oxalate crystals depends on the composition of the metabolites secreted by bacteria and fungi and therefore of the glucose concentration in the medium. The effect of the composition of the metabolites showed up significantly in experiments in humidity chamber: in B. subtilis monoculture and in B. subtilis with A. niger co-culture dipyramidal and dipyramidal-prismatic weddellite crystals formed accordingly (Figure 5). At low glucose concentrations 
( $1 \mathrm{~g} / \mathrm{L})$ in liquid medium containing B. subtilis and A. niger co-culture dipyramidal (almost isometric) weddellite crystals and stack-like intergrowths of plate whewellite crystals appeared (Figure 6a). At high glucose concentrations $(30 \mathrm{~g} / \mathrm{L})$ dipyramidal-prisms weddellite crystals and whewellite spherulitic intergrowths are appeared (Figure 6c). The development of weddellite prism faces in co-culture of $B$. subtilis and A. niger may be caused by the preferential adsorption of impurities present in the solution, e.g., citric acid molecules on the prism faces [5].

The obtained results clarified that in biotechnologies utilizing B. subtilis-as well as other oxalate producing bacteria-the time of the crystallization, as well as the thickness of carbonate crust can be controlled by variation of the amount of glucose in the medium. At the same time, it is necessary to take precautions to prevent contamination of the marble surface by different airborne microbe. As our experience shows, regular routine care associated with the chemical cleaning of the surface of marble monuments can significantly reduce the number of microorganisms (first of all, microscopic fungi) on the rock surface [42]. After such cleaning, it is possible to use "beneficial" bacteria to restore the surface of the monument, taking into account the specific parameters of the crystallization medium.

\section{Conclusions}

As a result of the conducted research a morphogenetic pattern of crystallization of calcium carbonates and oxalates induced by the metabolism of bacteria B. subtilis and by B. subtilis-A. niger association on marble surface was revealed.

It was shown that the metabolic activity of bacteria B. subtilis is a complex multifactorial process, the flow of which significantly depends on the cultivation trophic conditions, including the concentration of sugar in the medium. The metabolic activity of B. subtilis and A. niger association is vastly different from the activity of the separate monocultures which are in the same cultivation conditions. The composition of the metabolites secreted by bacteria and fungi (the first, the ratio between the EPS and oxalic acid concentration) significantly affects $\mathrm{pH}$ values of the crystallization medium and, as a result, the phase composition and morphology of the precipitating crystals. In turn, the $\mathrm{pH}$ of the medium significantly affects the metabolism of microorganisms. Depending on the cultivation conditions, crystallization of carbonates under the influence of bacterial-fungal associations can turn into crystallization of oxalates and vice versa. The morphology of calcium oxalates is controlled by the chemical composition of the crystallization medium and can be explained by selective adhesion of cultural broth components on the faces of growing crystals.

The present results obtained by laboratory research can be applied for the purposes of open air systems.

Author Contributions: Conceptualization (D.Y.V., O.V.F.-K. and K.V.S.); investigation (K.V.S., M.S.Z., A.D.V. and A.V.R., M.A.P.); methodology (K.V.S., M.S.Z., D.Y.V. and O.V.F.-K.); visualization (A.V.R. and M.S.Z.); writing—original draft (K.V.S. and A.D.V.); writing—review \& editing (A.V.R., D.Y.V. and O.V.F.-K.). All authors have read and agreed to the published version of the manuscript.

Funding: The research was funded by the Russian Science Foundation (grant 19-17-00141).

Acknowledgments: The laboratory studies were carried out in the Research Resource Centers of Saint Petersburg State University: SEM and EDX investigations-in the Resource Centers "Development of molecular and cell technologies" and "Nanotechnology" and XRD measurements-in the X-ray Diffraction Center.

Conflicts of Interest: The authors declare no conflict of interest.

\section{References}

1. Boniek, D.; MendesIsolda, I.C.; Abreu, C.M.; Abreu, O.C.; Show, O.; Stoianoff, M.A.R. Ecology and identification of environmental fungi and metabolic processes involved in the biodeterioration of Brazilian soapstone historical monuments. Lett. Appl. Microbiol. 2017, 65, 1-8. [CrossRef] [PubMed]

2. Warscheid, T.; Braams, J. Biodeterioration of stone: A review. Int. Biodeterior. Biodegrad 2000, 46, $343-368$. [CrossRef] 
3. Sterflinger, K. Fungi: Their role in deterioration of cultural heritage. Fungal Biol. Rev. 2010, 24, 47-55. [CrossRef]

4. Gadd, G.M.; Bahri-Esfahani, J.; Li, Q.; Rhee, Y.J.; Wei, Z.; Fomina, M.; Liang, X. Oxalate production by fungi: Significance in geomycology, biodeterioration and bioremediation. Fungal Biol. Rev. 2014, 28, 36-55. [CrossRef]

5. Sturm, E.V.; Frank-Kamenetskaya, O.V.; Vlasov, D.Y.; Zelenskaya, M.S.; Sazanova, K.V.; Rusakov, A.V.; Kniep, R. Crystallization of calcium oxalate hydrates by interaction of calcite marble with fungus Aspergillus niger. Am. Miner. 2015, 100, 2559-2565. [CrossRef]

6. Scheerer, S.; Ortega-Morales, O.; Gaylarde, C. Microbial deterioration of stone monuments-An updated overview. Adv. Appl. Microbiol. 2009, 66, 97-139. [CrossRef]

7. Savvides, A.L.; Nikolakopoulou, T.L.; Kyratsous, N.; Katsifas, E.A.; Kanini, G.; Karagoun, A.D. Bacterial Deterioration of Marble Monuments: A Case Study of the Conservation Project of Acropolis Monuments. Geomicrobiol. J. 2014, 31, 726-736. [CrossRef]

8. Cao, C.; Jiang, J.; Sun, H.; Huang, Y.; Tao, F.; Lian, B. Carbonate Mineral Formation under the Influence of Limestone-Colonizing Actinobacteria: Morphology and Polymorphism. Front. Microbiol. 2016, 7, 366. [CrossRef]

9. Anbu, P.; Kang, C.-H.; Shin, Y.-J.; So, J.-S. Formations of calcium carbonate minerals by bacteria and its multiple applications. Springerplus 2016, 5, 250. [CrossRef]

10. Muynck, W.D.; Belie, N.D.; Verstraete, W. Microbial carbonate precipitation in construction materials: A review. Ecol. Eng. 2010, 36, 118-136. [CrossRef]

11. Chen, L.; Xie, A.; Jia, R.; Shen, Y.; Tang, W.; Li, C. Influence of Bacillus subtilis on the growth of calcium oxalate. Cryst. Res. Technol. 2007, 42, 881-885. [CrossRef]

12. Zhu, T.; Dittrich, M. Carbonate Precipitation through Microbial Activities in Natural Environment, and Their Potential in Biotechnology: A Review. Front. Bioeng. Biotechnol. 2016, 4, 4. [CrossRef] [PubMed]

13. Al-Abbasi, R.R. Quantification of Exopolysaccharide Produced by Bacillus subtilis and the Effect of Different Factors on its Production. Raf. J. Sci. 2018, 27, 82-91.

14. Monte, M. Oxalate film formation on marble specimens caused by fungus. J. Cult. Herit. 2003, 4, $255-258$. [CrossRef]

15. Sazanova, K.V.; Vlasov, D.Y.; Osmolovskay, N.G.; Schiparev, S.M.; Rusakov, A.V. Significance and regulation of acids production by rock-inhabited fungi. In Biogenic-Abiogenic Interactions in Natural and Anthropogenic Systems. Lecture Notes in Earth System Sciences; Frank-Kamenetskaya, O., Panova, E., Vlasov, D., Eds.; Springer: Cham, Switzerland, 2016; pp. 379-392. [CrossRef]

16. Keshari, N.; Adhikary, S.P. Characterization of cyanobacteria isolated from biofilms on stone monuments at Santiniketan, India. Biofouling 2013, 29, 525-536. [CrossRef]

17. Gilbert, P.; Maira-Litran, T.; McBain, A.J.; Rickard, A.H.; Whyte, F.W. The physiology and collective recalcitrance of microbial biofilm communities. Adv. Microb. Physiol. 2002, 46, 203-256.

18. Boonchan, S.; Britz, M.L.; Stanley, G.A. Degradation and mineralization of high-molecular weight polycyclic aromatic hydrocarbons by defined fungal-bacterial cocultures. Appl. Environ. Microbiol. 2000, 66, 1007-1019. [CrossRef]

19. Berdoulay, M.; Salvado, J.C. Genetic characterization of microbial communities living at the surface of building stones. Lett. Appl. Microbiol. 2009, 49,311-316. [CrossRef]

20. Achal, V.; Mukherjee, A. A review of microbial precipitation for sustainable construction. Constr. Build. Mater. 2015, 93, 1224-1235. [CrossRef]

21. Wang, R.; Qian, C. In situ restoration of the surface defects on cement-based materials by bacteria mineralization with spraying method. J. Wuhan Univ. Technol. Mat. Sci. Ed. 2014, 29, 518-526. [CrossRef]

22. Dejong, J.T.; Fritzges, M.B.; Nüsslein, K. Microbially induced cementation to control sand response to undrained shear. J. Geotech. Geoenviron. Eng. 2006, 132, 1381-1392. [CrossRef]

23. Reeder, R.J.; Lamble, G.M.; Northrup, P.A. XAFS study of the coordination and local relaxation around $\mathrm{Co}^{2+}$, $\mathrm{Zn}^{2+}, \mathrm{Pb}^{2+}$, and $\mathrm{Ba}^{2+}$, trace elements in calcite. Am. Miner. 1999, 84, 1049-1060. [CrossRef]

24. Kumari, D.; Quan, X.-Y.; Pan, X.; Achal, V.; Li, Q.; Gadd, G.M. Microbially-induced Carbonate Precipitation for Immobilization of Toxic Metals. Adv. Appl. Microbiol. 2016, 94, 79-108. [CrossRef]

25. Lin, W.; Huang, Z.; Li, X.; Liu, M.; Cheng, Y. Bio-remediation of acephate-Pb(II) Compound Contaminants by Bacillus Subtilis FZUL-33. J. Environ. Sci. 2016, 45, 94-99. [CrossRef] 
26. Rusakov, A.V.; Vlasov, A.D.; Zelenskaya, M.S.; Frank-Kamenetskaya, O.V.; Vlasov, D.Y. The crystallization of calcium oxalate hydrates formed by interaction between microorganisms and minerals. In Biogenic-Abiogenic Interactions in Natural and Anthropogenic Systems. Lecture Notes in Earth System Sciences; Frank-Kamenetskaya, O., Panova, E., Vlasov, D., Eds.; Springer: Cham, Switzerland, 2016; pp. 357-377. [CrossRef]

27. Castanier, S.Ł.; Métayer-Levrel, G.; Perthuisot, J.-P. Ca-carbonates precipitation and limestone genesis-The microbiogeologist point of view. Sediment. Geol. 1999, 126, 9-23. [CrossRef]

28. Stocks-Fischer, S.; Galinat, J.K.; Sookie, S. Microbiological precipitation of $\mathrm{CaCO}_{3}$. Bang Soil Biol. Biochem. 1999, 31, 1563-1571. [CrossRef]

29. Wei, S.; Cui, H.; Jiang, Z.; Liu, H.; He, H.; Fang, N. Biomineralization processes of calcite induced by bacteria isolated from marine sediments. Braz. J. Microbiol. 2015, 46, 455-464. [CrossRef]

30. Marvasi, M.; Gallagher, K.L.; Martinez, L.C.; Pagan, M.W.C.; Santiago, R.E.R.; Vega, G.C.; Vissche Pieter, T. Importance of B4 Medium in Determining Organomineralization Potential of Bacterial Environmental Isolates. Geomicrobiol. J. 2012, 29, 916-924. [CrossRef]

31. Perito, M.B.; Buccianti, R.A.; Passaponti, M.; Montegrossi, G.; Di Benedetto, F. An XRPD and EPR spectroscopy study of microcrystalline calcite bioprecipitated by Bacillus subtilis. Phys. Chem. Miner. 2018, 45, 935-944. [CrossRef]

32. Dhami, N.K.; Reddy, S.M.; Mukherjee, A. Biomineralization of Calcium Carbonate Polymorphs by the Bacterial Strains Isolated from Calcareous Sites. J. Microbiol. Biotechnol. 2013, 23, 707-714. [CrossRef]

33. Li, W.; Liu, L.; Chen, W.; Yu, L.; Li, W.; Yu. H. Calcium carbonate precipitation and crystal morphology induced by microbial carbonic anhydrase and other biological factors. Process Biochem. 2010, 45, 1017-1021. [CrossRef]

34. Ronholm, J.; Schumann, D.; Sapers, H.M.; Izawa, M.; Applin, D.; Berg, B.; Mann, P.; Vali, H.R.; Flemming, L.; Cloutis, E.A.; et al. Amineralogical characterization of biogenic calcium carbonates precipitated by heterotrophic bacteria isolated from cryophilic polar regions. Geobiology 2014, 12, 542-556. [CrossRef]

35. Gorospe, C.M.; Han, S.-H.; Kim, S.-G.; Park, J.-Y.; Kang, C.-H.; Jeong, J.-H.; So, J.-S. Effects of Different Calcium Salts on Calcium Carbonate Crystal Formation by Sporosarcina pasteurii KCTC 3555. Biotechnol. Bioprocess Eng. 2013, 18, 903-908. [CrossRef]

36. Somova, N.G.; Dobrovol'skaya, T.G.; Zenova, G.M.; Ivanovskii, R.N. Microbial growth of the masonry surface: Synecological analysis. Microbiology 1998, 67, 569-574.

37. Kurakov, A.V.; Somova, N.G.; Ivanovskii, R.N. Micromycetes populating limestone and red brick surfaces of the Novodevichii Convent masonry. Microbiology 1999, 68, 232-241.

38. Savadogo, A.C.; Ouattara, A.T.; Savadogo, P.W.; Barro, N.; Ouattara, A.S.; Traore, A.S. Identification of exopolysaccharides-producing lactic acid bacteria from Burkina Faso fermented milk samples. Afr. J. Biotechnol. 2004, 3, 189-194.

39. Ghorbani, Y.; Oliazadeh, M.; Shahvedi, A.; Roohi, R.; Pirayehgar, A. Use of some isolated fungi in biological Leaching of Aluminum from low grade bauxite. Afr. J. Biotechnol. 2007, 6, 1284-1288.

40. Maruthamuthu, S.; Dhandapani, P.; Ponmariappan, S.; Bae, J.-H.; Palaniswamy, N.; Rahman, P.K.S.M. Impact of ammonia producing Bacillus sp. on corrosion of cupronickel alloy 90:10. Met. Mater. Intl. 2009, 15, 409-419. [CrossRef]

41. Kuz'mina, M.A.; Rusakov, A.V.; Frank-Kamenetskaya, O.V.; Vlasov, D.Y. The influence of inorganic and organic components of biofilms with microscopic fungi on the phase composition and morphology of crystallizing calcium oxalates. Cryst. Rep. 2019, 64, 161-167. [CrossRef]

42. Frank-Kamenetskaya, O.V.; Vlasov, D.Y.; Rytikova, V.V. (Eds.) The Effect of the Environment on Saint Petersburg's Cultural Heritage. Results of Monitoring the Historical Necropolis Monuments; Springer Nature Switzerland AG: Cham, Switzerland, 2019; 188p.

(C) 2020 by the authors. Licensee MDPI, Basel, Switzerland. This article is an open access article distributed under the terms and conditions of the Creative Commons Attribution (CC BY) license (http://creativecommons.org/licenses/by/4.0/). 